\title{
USE WEBSITE FOR LITERACY SCIENCE: COULD INCREASE SELF-INDEPENDENT LEARNING FOR STUDENTS IN ELEMENTARY SCHOOL?
}

\author{
Dewi Febriani ${ }^{1}$, Ika Lestari ${ }^{2}$, Fahrurrozi $^{3}$ \\ 1,2,3 Universitas Negeri Jakarta, Jakarta, Indonesia \\ Emal:1dewifebriani_1107618015@mhs.unj.ac.id ${ }^{2}$ ikalestarisartomo@gmail.com \\ 3 fahrurrozi_unj@yahoo.com
}

\begin{abstract}
The digital age in the pandemic requires self-reliance in learning. Toward to train and develop the character of student self-regulated learning, this website presents a media visualization that can support the improvement of feelings of student independence through science literacy activities. This research aims to develop student independence in elementary school used website media that provides content in science literacy activities. The sample of this study is second-grade students from Pondok Kelapa 04 elementary school, East Jakarta, Indonesia, in the 2020/2021 school year. The results showed that a media site is known as Wetracy (Website for Literacy) influenced the development of the character of independence of second-grade students in science literacy activities. Thus, the study concluded that website media could effectively stimulate student's self-reliance character in science literacy.
\end{abstract}

Keywords: independent character; literacy science; website; elementary school; self-reliance.

\section{INTRODUCTION}

Since the emergence of Covid-19, the world of education has presented under new demands where students require students to study online include in Indonesia. Online learning is a new policy where not all students, teachers, and parents are ready for this online learning activity (Morgan, 2020). Therefore, it is significant to consider some aspects necessary in supporting online learning as optimizing changes in the use of learning strategies, technological readiness to supported learning, and form of motivational support between teachers, students, and parents that integrated into learning at home (Rasmitadila et al., 2020). In addition, character education also has been substantial role to be able to help students in carrying out online learning (Intania \& Sutama, 2020). One of the values of character education that must instill in students during online learning is the character of self-reliance (School, 2020). It is mention by MoEC (Ministry of Education and Culture) that the profile of Indonesian students consists of 5 characters, one of which is the character of self-reliance (UNICEF, 2021). Therefore, the school must optimize learning that contains aspects of independence with good cooperation between the education component and 
students to succeed in planting this independent character. Schools also need to have good relations with the government, teachers, parents, and local communities (Çoruk, 2018).

Self-reliance is one of the essential characteristics of humans (Mujahidin et al., 2018). Through self-reliance, one can develop critical thinking skills (Kopzhassarova et al., 2016). The independence possessed by each defines as the ability to act and be responsible for their actions and make their own decisions and not depend on others (Agung, Iskandar, Widiputera, Ferdi \& Widodo., 2019). The character of independence aims for a person to have decision-making skills and the ability to control emotions so as not to depend on others (Shaffer \& Kipp, 2010). The character of independence builds by oneself realizing that character is not easy (Dwyer, 2012). Planting and increase self-reliance must be done early. It has characterized the period of age 6 to 14 years as a necessary period for children in shaping the progress of character inclusive developing selfreliance (Eccles, 1999).

The implementation of online learning is now slowly increasingly demanding students to study independently at home (Nurazizah, 2021). Because, with an independent attitude, it will make it easier for students to follow online learning because teachers can not directly accompany them during the learning process. Explains by a study that shows that independent character during online learning can be instilled and developed in students in elementary school through synergy between parents and teachers in building an independent character (Rosilia et al., 2020). In line with the research conducted to four elementary schools in Semarang, Indonesia, in the successful application of self-reliance values in 2018, self-reliance in strengthening character education in elementary school has been good and become a school culture. However, there are still schools that are not optimal in implementing the values of independence (Muttaqin et al., 2018). The planting of self-reliance value should support several aspects, such as using the ARCS learning model to maximize the students' independence in elementary schools (Lumbantobing \& Haryanto, 2019). Research at the junior high school level says that applying 
brainstorming techniques can improve and hone learners' independence (Royana et al., 2019).

In addition, the character of a student's independence can train through self-development activities, subject cohesion, and school culture (Puspitaningrum \& Ismaniati, 2020). Other factors can support student independence, such as the procurement of a special task force in elementary schools that have to realize character values include the value of student independence in the Character Education Strengthening program (Prasetiyo \& Baswedan, 2020). In addition, selfregulated learning owned by each student is also one of the factors that can affect the independence of learners in learning (Sukowati et al., 2020). Other research findings related to the character of student independence, namely teacher evaluation and assessment of student independence, can be done using a mobile-based instrument (e-assessment) (Asrial et al., 2020).
Based on all research results, stated that the character of independent students in elementary school through online learning still needs to be developed. Based on previous research, more discuss various models and techniques to build the character selfreliance during online learning. Nevertheless, there has been no research on the relevance of self-reliance character to digital literacy science. Therefore, this research aims to develop the character student of self-reliance through website-based science digital literacy activities.

Based on this, to see the success in improving student's independence in elementary school, research has carried on 130 students in grades 4, 5, and 6. The following are the learning outcomes in Table 1 Student independence in Batanghari Elementary School. Here are the results of the study in table 1 Independence of students in the Batanghari elementary school. 
Table 1. Independence of students in the Batanghari elementary school

\begin{tabular}{|c|c|c|c|c|c|c|}
\hline \multicolumn{3}{|c|}{ Classification } & \multirow{2}{*}{ Mean } & \multirow{2}{*}{ Min } & \multirow{2}{*}{ Max } & \multirow{2}{*}{$\%$} \\
\hline Range & Independece & Total & & & & \\
\hline $24.0-43.2$ & Not very good & 0 & \multirow{5}{*}{92} & \multirow{5}{*}{45} & \multirow{5}{*}{117} & 0.0 \\
\hline $43.3-62.4$ & Not good & 0 & & & & 0.0 \\
\hline $62.5-81.6$ & Enough & 27 & & & & 21.1 \\
\hline $81.7-100.8$ & Good & 70 & & & & 54.1 \\
\hline $100.9-120.0$ & Very Good & 32 & & & & 24.8 \\
\hline TOTAL & & 130 & & & & 100 \\
\hline
\end{tabular}

Based on the results of 130 respondents primary school students in Batanghari, show the independence of learners in thematic learning has the best categories of $54.1 \%$ for 70 students out of a total of 130 students. Therefore, it indicates that student independence is good but still needs to be improved again.

A preliminary study conducted on grade 2 teachers of Pondok Kelapa 04 primary School, East Jakarta, Indonesia, said that teachers have difficulty controlling or supervising student's behavior directly. However, it does not close the possibility of teachers teaching character values with the cooperation of parents at home. Therefore, character formation must continue to be optimized to equip students as the golden generation of Indonesia in 2045 in facing the dynamics of change in the future. In addition, character-building also aims to develop the foundation of national education, especially character education as the foremost soul, by paying attention to multicultural aspects as stated in the Strengthening Character Education program (Kemendikbud, 2016). So, this research aims to develop the character of independence of students in elementary schools using the media website through science literacy activities.

\section{RESEARCH METHODOLOGY}

\section{A. DESIGN-BASED RESEARCH}

This research is a media development research using design-based research 
methods. The development model in this study refers to the Hannafin \& Peck model. The design and development carried out at the Hannafin \& Peck stage are illustrated in Figure 1.

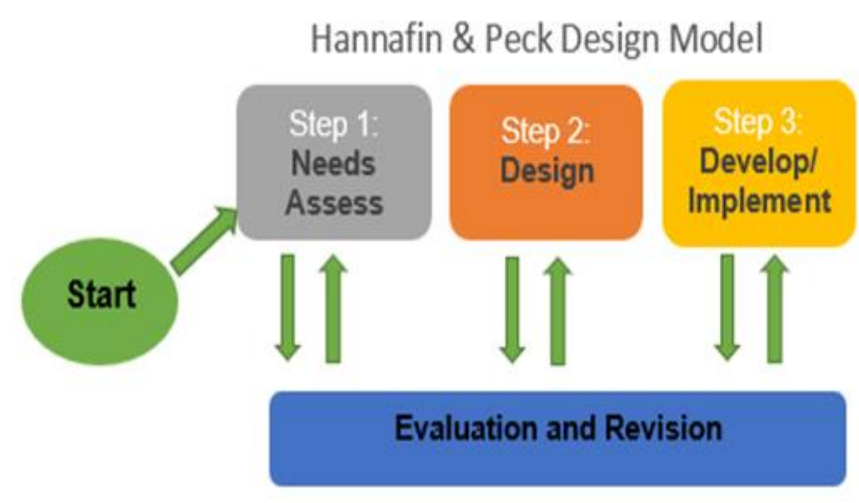

Figure 1. Stage in the development model of Hannafin \& Peck

The three stages involve evaluation and revision stages, while this study only uses two-stage of Hannafin \& Peck development model, namely the needs analysis stage and design stage, with thefollowing explanations:

\section{a) Needs Analysis}

At this stage, the researcher conducts a needs analysis on the characteristics of the research sample. The activity was through interviews with grade 2 teachers of Pondok Kelapa Elementary School 04, Jakarta, Indonesia. In addition, the researchers distributed questionnaires to as many as 23 instruments divided into seven indicators of independence character. This questionnaire was measured using a Likert scale and addressed to 25 students of grade 2 of the 2020/2021 school year at Pondok Kelapa Elementary School 04, Jakarta, Indonesia, who participated in online learning activities. The results of the analysis of the needs carried out become the basis in the development of media.

\section{b) Design}

At this stage, researchers developed a media design based on the results of analysis of the needs of students in grade 2 of Pondok Kelapa Elementary School 04, Jakarta, Indonesia, by creating a 
flowchart to provide an overview of the structure and content of science literacy in the website.

\section{c) Development and Implementatio}

At this stage, researchers create and develop media designs and apply them according to research objectives and based on the needs of students.
The research technique used is a questionnaire of the independent character of learners during online learning before utilizing the website media as science literacy. The variables of self-reliance character described with indicators-indicators are poured into 23 instruments in table 1 as follows.

\section{B. DESIGN-BASED RESEARCH INSTRUMENTS}

Table 2. Student Self-Reliance Character Instrument

\begin{tabular}{|c|c|c|}
\hline Variable & Indicators & Observed Aspects \\
\hline \multirow[t]{8}{*}{$\begin{array}{l}\text { The Character } \\
\text { of Self- } \\
\text { Reliance }\end{array}$} & $\begin{array}{l}\text { Work Ethic (Hard } \\
\text { Work) }\end{array}$ & $\begin{array}{l}\text { 1.1 have perseverance in doing the task to the end } \\
1.2 \text { rush to do everything } \\
1.3 \text { able to fight laziness in learners. } \\
\text { 1.4 Delaying in performing a given task }\end{array}$ \\
\hline & $\begin{array}{l}\text { Tough Slam } \\
\text { Resistance }\end{array}$ & $\begin{array}{l}\text { 2.1 depending on the help of others } \\
\text { 2.2 Despair when failure } \\
2.3 \text { using the time to study earnestly to get good results } \\
2.4 \text { constantly try something until it can and find a } \\
\text { solution }\end{array}$ \\
\hline & Fight Power & $\begin{array}{l}\text { 3.1 have a disciplined attitude in learning } \\
3.2 \text { not eager to follow learning } \\
3.3 \text { can be held accountable for everything that done }\end{array}$ \\
\hline & Professional & $\begin{array}{l}\text { 4.1 Listening to learning well } \\
\text { 4.2 Late in the class absence and collecting assignments } \\
\text { 4.3 Not confident in the results of self-employment } \\
\text { 4.4 being polite during online learning }\end{array}$ \\
\hline & Creative & $\begin{array}{l}\text { 5.1 able to provide ideas or solutions for troubleshooting } \\
5.2 \text { lack of curiosity } \\
\text { 5.3 Interested in learning new things }\end{array}$ \\
\hline & Courage & $\begin{array}{l}6.1 \text { not dare to ask the teacher } \\
6.2 \text { fear of admitting wrongdoing and reluctant to } \\
\text { apologize } \\
6.3 \text { not dare to tell the truth }\end{array}$ \\
\hline & Become a Lifelong & 7.1 have tenacity in learning \\
\hline & Learner & 7.2 dislike change and something new \\
\hline
\end{tabular}

After disseminating questionnaires to students, the researchers then scored a described in table 2 as follows. category on each item of answer from the respondent. The scoring used can be 
Table 3. Self-Reliance Character Questionnaire Score

\begin{tabular}{ll}
\hline Criterion & Score \\
\hline Always & 4 \\
Often & 3 \\
Infrequently & 2 \\
Never & 1 \\
\hline
\end{tabular}

Next step, the researchers determine the scale rating based on the results of the data obtained. The determination of the scale rating that has been creating can see in table 4.

Table 4. Self-Reliance Character Questionnaire Rating Scale

\begin{tabular}{ll}
\hline Answer Value & Scale / Criteria \\
\hline $76-100$ & Excellent \\
$51-75$ & good \\
$26-50$ & enough \\
$0-25$ & less \\
\hline
\end{tabular}

\section{RESULTS AND DISCUSSION}

\section{RESULTS OF STUDENT NEEDS} ANALYSIS

The independence of students to conduct literacy activities during online learning is urgently needed. This independence is necessary because of the demands of online learning process, where teachers have limited access to reach students. The character is essential because students need to explore knowledge and information independently, where most of what students need to sourcing from the internet. Therefore, researchers develop media in websites that can be accessed anytime and anywhere by students. This website is designed based on the results of the analysis of student needs during online learning. The analysis results say that most students feel familiar with the word website but have never used it because variations in learning media have not varied.

The result of the student selfreliance character questionnaire during online learning before using the website media as overall science literacy showed that the character of student self-reliance 
is already well categorized. These results

can see in table 5 .

Table 5. Results of Analysis of Overall Self-Reliance Character Questionnaire Before Using Media

\begin{tabular}{cccccc}
\hline Respondents & $\begin{array}{c}\text { Score } \\
\text { Range }\end{array}$ & Mean & Mood & Median & $\begin{array}{c}\text { Standard } \\
\text { Deviation }\end{array}$ \\
\hline 25 students & $52.17-80.43$ & 67.65 & 66.30 & 67.39 & 8.931 \\
\hline
\end{tabular}

Based on the table above, the value range of 25 learners is at 52.17-80.43, which means the character of student independence is good enough when viewed from the overall calculation of 23 instruments of a self-reliance character statement. Then for the average of 67.65 shows that the majority of learners have good independence during online learning. Thus, there are 6 out of 25 students who have excellent independence. However, this shows that the character of student independence, especially in online learning, still needs to be improved.
The variable character independence of learners is categorized based on their respective indicators, namely work ethic (hard work), resilient hardness, fighting power, professionalism, creativity, courage, and become learners throughout life. Based on the data, researchers found indicators of the courage of learners who categorize as more minor with a score of 25 out of 7 indicators of variable character independence of learners. Therefore, the results of observations made by teachers are not much different from the results of questionnaire research presented in table 6 .

Tabel 6. Results of Student Independence Character Questionnaire

\begin{tabular}{llll}
\hline No. & Indicators & Score & Criterion \\
\hline 1. & Work Ethic (Hard Work) & 77 & Excellent \\
\hline 2. & Tough Slam Resistance & 79.75 & Excellent \\
\hline 3. & Fighting Power & 84 & Excellent \\
\hline 4. & Professional & 83 & Excellent \\
\hline 5. & Creative & 59.3 & Good \\
\hline 6. & Courage & 25 & Less \\
\hline 7. & Become a Lifelong Learner & 45.5 & Enough \\
\hline
\end{tabular}


Based on the data in table 5, the in the independent variable, the courage character of students' independence indicator is still in the less category and during online learning can be said to needs to develop.

have been categorized very well on the indicators of work ethic (hard work), resilience, fighting power, and professionalism. The creative indicator is suitable while being a lifelong learner is in a good category. Of all the indicators

\section{WETRACY MEDIA DESIGN}

The media literacy website designed and developed in this study is known as Wetracy (Website of Literacy). Wetracy's design can be seen from the following flowchart.

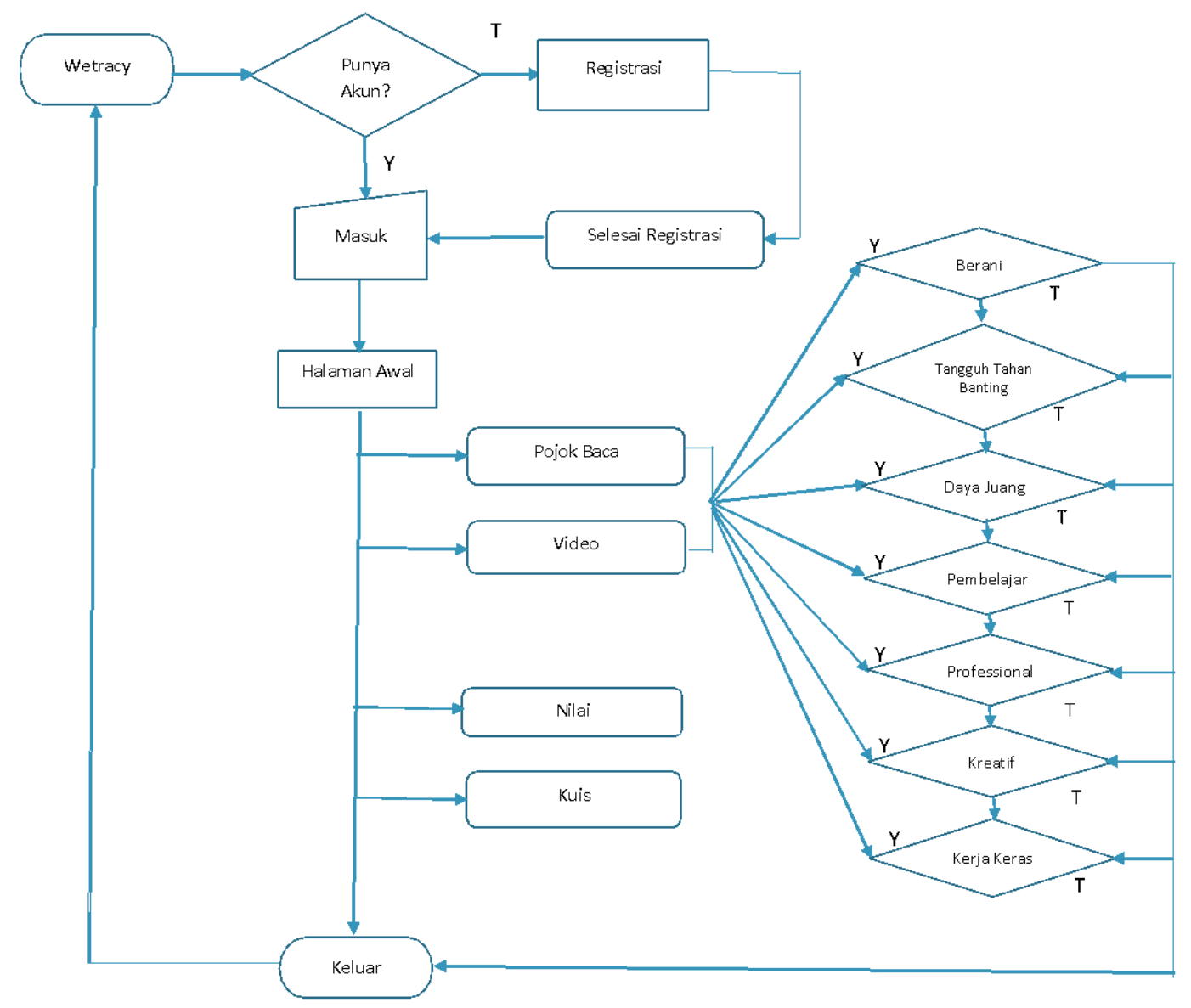

Figure 2. Flowchart Wetracy

Wetracy consists of 3 main menus, score from the acquisition of quiz namely reading corner, video, quiz, and results. Before using this website, users 
will be direct to $\log$ in or register an account first, and parts of Wetracy's main menu can see in figures 4 and 5 . Wetracy's reading corner content and videos are adapt to scientific literacy and aspects of the independent character of students. In each reading corner, content is classified accord to independent character indicators by presenting readings according to the content of scientific literacy material. On the quiz menu, students will give some questions to assess learners' behavior or attitude after using Wetracy, and knowing the percentage could see in the value menu.

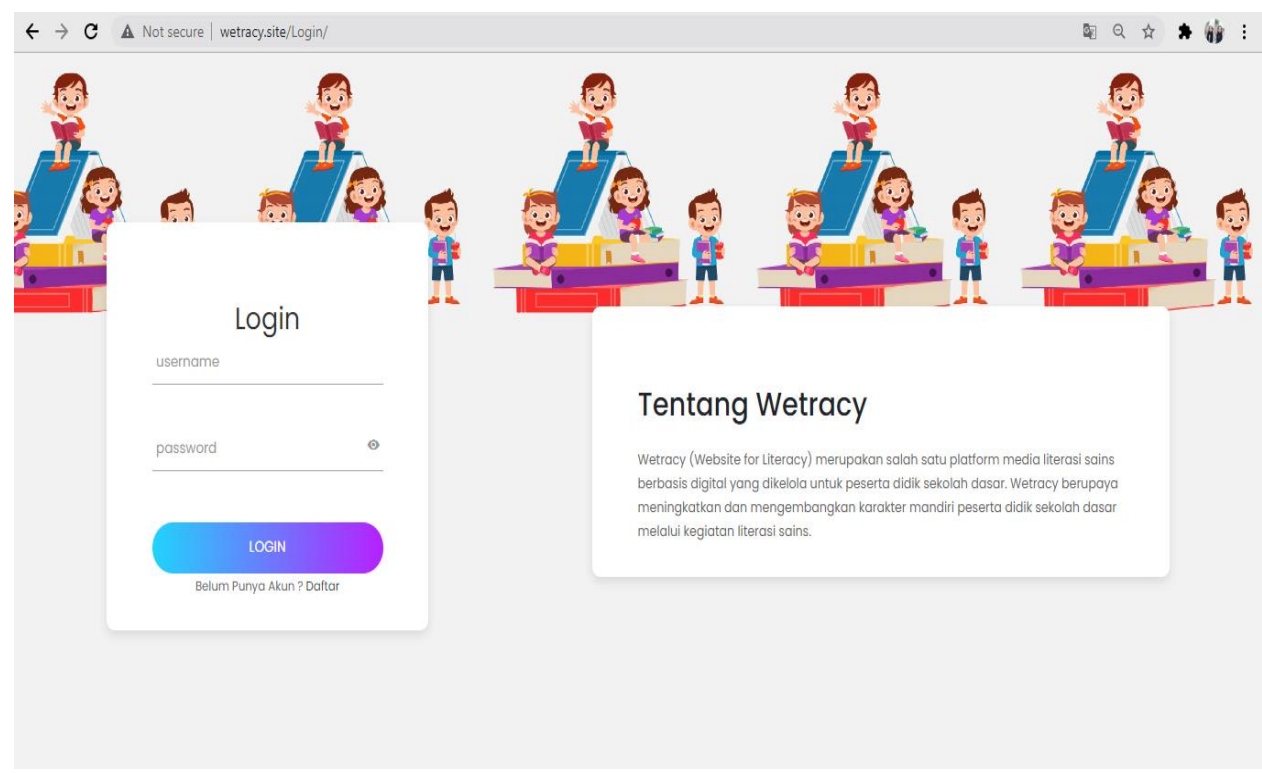

Figure 4. Wetracy Home Page View

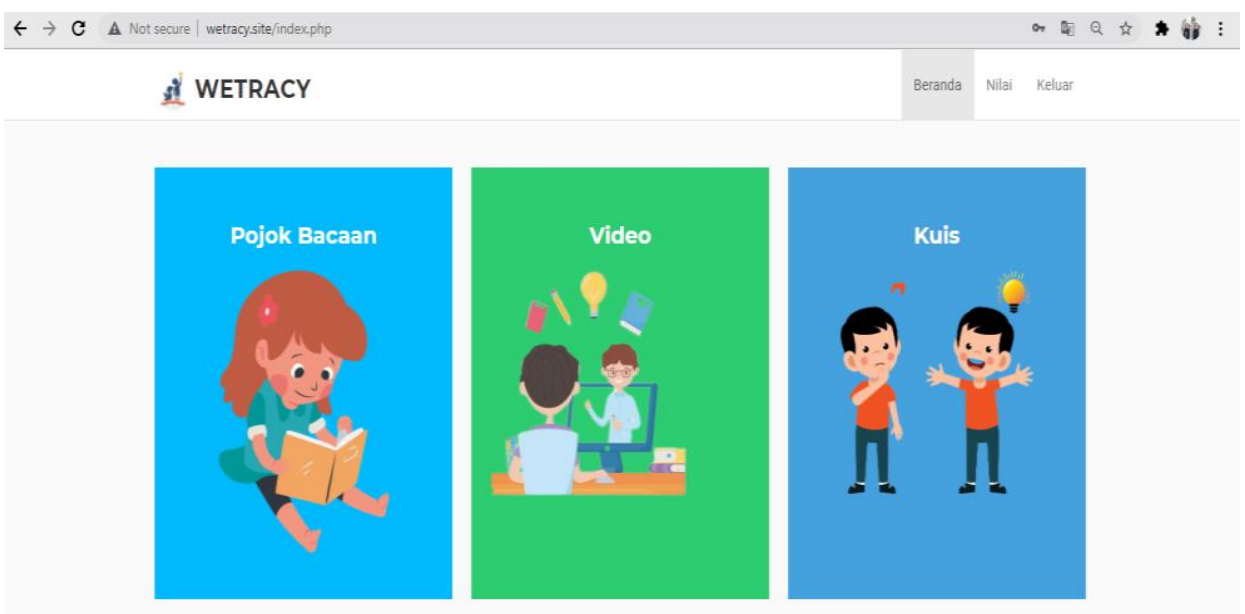

Wetracy (Website for Literacy) mendukung Peserta Didilk Sekolah Dasar untuk membudayakan literasi sains

Figure 5. Wetracy Main Menu View 


$\begin{array}{ll}\text { WETRACY MEDIA EXPERT } & \text { results used to measure the feasibility of } \\ \text { VALIDATION } & \text { Wetracy media can be seeing in the table } \\ \text { Wetracy media has been testing by three } & \text { below. }\end{array}$

experts, namely media experts, material experts, and linguists. The validation

Table 7. Percentage of Media Expert Eligibility

\begin{tabular}{llll}
\hline No & Assessment Aspect & Percentage & Category \\
\hline 1 & Usability & $80 \%$ & Proper \\
\hline 2 & Functionality & $80 \%$ & Proper \\
\hline 3 & $\begin{array}{l}\text { Visual } \\
\text { Communication }\end{array}$ & $100 \%$ & Very Decent \\
\hline & Average Score & $86.67 \%$ & Very Decent \\
\hline
\end{tabular}

Based on the table above, three aspects of assessment from media experts: usability, functionality, and visual communication. The average score shows Wetracy media is in the category of "very decent," with a percentage of $86.67 \%$ in terms of its media. Suggestions for improvement received from media experts regarding the development of Wetracy media are that Wetracy should make without providing an account reminder feature; in case of use, the account feature should send it via email for a reminder. Then the results of the validation in terms of material experts can be explained in the following table.

Table 8. Percentage of Material Expert Eligibility

\begin{tabular}{cccc}
\hline No & Assessment Aspect & Percentage & Category \\
\hline 1 & Learning Design & $93.3 \%$ & Very Decent \\
\hline 2 & Materials & $100 \%$ & Very Decent \\
\hline & Average Score & $96.95 \%$ & Very Decent \\
\hline
\end{tabular}


The table above shows two aspects of the assessment of material experts, namely elements of learning design and content or material. The average score for Wetracy media material can be categorized as "very decent," with a percentage of $96.65 \%$. Constructive criticism by material experts adds activities or questions to the Wetracy menu to support learners' independence. The following validation result is in terms of linguists, which can be seen from the exposure table below.

Table 9. Percentage of Linguist Expert Eligibility

\begin{tabular}{llll}
\hline No & Assessment Aspect & Percentage & Category \\
\hline 1 & Language and Communication & $100 \%$ & Very Decent \\
\hline 2 & Ethics & $100 \%$ & Very Decent \\
\hline & Average Score & $100 \%$ & Very Decent \\
\hline
\end{tabular}

Based on the table above, two aspects are assessed in terms of linguists: language, communication, and ethics. The average score shown from the table states that Wetracy media in terms of linguists are categorized as "very decent" with a percentage of $100 \%$.

\section{DISCUSSION}

\section{EFFECT OF WEBSITE MEDIA USE ON CHARACTER DEVELOPMENT OF STUDENT INDEPENDENCE}

The essence of each individual's character form can be formed and influenced by many aspects. As the primary step in terms of educating, parents and families first instill characters in children. Furthermore, the character dominates when the child becomes a student within the scope of learning in school. As parents of students in school and providing knowledge, teachers also need to give examples and monitor their students' behavior and attitudes. Therefore, character planting is one of the essential parts of the world of education. This statement is in line with the education system of $\mathrm{Ki}$ Hajar Dewantara, which puts forward the values of character in it (Suwardani, 2020).

Based on the character education strengthening program launched by the Ministry of Education and Culture, there 
is a planting of prioritized character values, such as religious values, nationalist values, independent values, mutual values, and integrity values (Hendarman, 2017). Regarding character cultivation, one of the characters that are relevant during this pandemic is an independent character. Students are meant to study on their own at home, even without direct interaction with the teacher. In addition, discussions and interactions with peers are also limited. The existence of online learning during the pandemic makes independent characters visible as the learning activities occur online. To increase student independence, collaborative management of teachers and parents in running education at home and school needs to run well (Zhou et al., 2020).

In addition to the role of teachers and parents in instilling character, the contribution of media used in the learning process can stimulate the improvement of students' understanding in mastering certain materials. Media such as short films, videos, music, television, articles, and posts on websites or blogs can improve learning and help learners make certain concepts or ideas (Mateer et al., 2012). The use of learning media can also increase students' motivation at the elementary school level (Puspitarini \& Hanif, 2019). In addition, the use of media such as Macromedia flash can also function in developing and improving the character education of students (Suprani \& Hendracipta, 2019). Due to the various learning media today, factors such as the effectiveness and suitability of the media users need to be considered because all learning media will be successful and effectively used if it is following what is to be delivered.

Therefore, website-based media is the choice of researchers in addressing the problem of planting and developing self-reliance character that is indispensable during online learning. The statement was relevant to the research results using websites that effectively instilled learners' character and independence (Maharani \& Dewi, 2015). Other research also said that learners' independence could be improved through problem-based learning using the website (Setyowidodo et al., 2018). Based on previous research, researchers aim to develop and enhance student independence with breakthroughs, namely by developing a media website containing science 
literacy activities. Therefore, researchers designed website media content with a form of science literacy activities to direct and trigger learners in growing and developing the character of their independence.

In line with the researchers' objectives, literacy activities become an effort that is considered adequate and relevant in fostering a literacy culture. However, it is also worth noting that literacy is not just reading and writing. Mathematics and science literacy are also considered very important for the future with technological and scientific advances (OECD, 2003). In today's digitalization era, digital literacy also supports the development of student literacy at home. Research studies in Istanbul say that digital literacy can develop a positive attitude towards reading and motivating children at the age of $6-7$ years to read activities in the future (Ozturk \& Ohi, 2018). Therefore, researchers use website media as a forum to develop the character of student independence through digital science literacy activities by utilizing website media.

\section{CHARACTERISTICS}

OF

\section{WETRACY MEDIA}

The result of the development of this website media is known as Wetracy (Website for Literacy). Wetracy is a medium designed for the study analysis of the needs of grade 2 students during online learning at Pondok Kelapa Elementary School 04, Jakarta, Indonesia. Wetracy has the characteristics that distinguish it from the media of the website in general. The first characteristic of Wetracy is that it can present an atmosphere of science literacy activities that are different from before. In addition to digital access, Wetracy provides a reading corner menu themed on science and self-attitude in each reading content.

Furthermore, all readings are equipped with exciting cartoon illustrations accompanied by short writing to avoid saturation at the time of reading according to the abilities and characteristics of grade 2 students. It is stated that children 6-8 years old age, where they can do play and learning activities such as reading, identifying new words, and taking simple science experiments (Education, 2018). Therefore, Wetracy strives to maximize 
educational content that can hone learners' independence through science literacy activities by the ability of grade 2 students.

The second characteristic lies in the themes of reading in Wetracy that are selected to support critical thinking processes in learners. The series of stories and conversations of characters in reading contains scientific facts to encourage the science capabilities of the learners. Then, the science literacy reading figures are humans and animals identified as having characters such as brave, hard work, challenge, confidence, not dependent on others, being professional, having curiosity, and always wanting to learn new things. It can build the reading skills of grade 2 students by starting to respond to characters in stories, understand important ideas or concepts in stories, and understand more complex words (Scholastic Parents Staff, 2020). Through the learner's response to his interest in a reading, this becomes one aspect so that the learner has the attitude to be a lifelong learner who is in an independent character.

The third characteristic, in addition to reading resources that support the advancement of student independence, the presence of video content in Wetracy is also an attraction for students. Because in 2018, most of the study results, students aged 8-11 years tend to choose streaming videos on Youtube rather than watching shows on television (Gilchrist \& Polizz, 2019). That indicates that video has a considerable influence on learners. Therefore, video can function as a medium for various educational purposes. The utilization of video in the world of education can also increase motivation, material understanding, and learners' knowledge (Beheshti et al., 2018). Video as an audiovisual medium is also proven to disseminate scientific information in its involvement with science (Ferraro et al., 2019). That will add to the students' self-reliant attitude because Wetracy provides some video content in simple science experiments that can be tried at home. In addition, Wetracy also provides fable story videos that can entertain and educate students implicitly about the importance of having an attitude of self-reliance. Then the fourth characteristic of Wetracy is the existence of a quiz menu containing questions in the form of multiple-choice into an assessment of attitude changes 
that can help teachers and parents analyze and know the development of independent characters owned by students during the use of Wetracy.

\section{EXCELLENCE}

AND

\section{RELATIONSHIP OF WETRACY} MEDIA WITH THE CHARACTER OF STUDENT SELF-RELIANCE

Each learning medium has its advantages. Similarly, Wetracy media, based on the results of research that has been done, also has the advantage of, among others, the first, the content on Wetracy is exciting, fun, and following the character of students aged 7-8 years or grade 2 elementary school. Second, Wetracy includes a website that can be accessed online through a laptop, pc, or device that supports a web browser so that it is flexible and the process of access to the website is relatively fast. Third, Navigation on Wetracy is also made simple to make it easier for learners to use and select the desired features. Fourth, Wetracy also provides download access to the reading corner menu so that students can read stories or read offline. Fifth, Wetracy has two components for admins (teachers) and dynamic students. Finally, although Wetracy has advantages in its application, Wetracy also has flaws in terms of content that students can only use in grade 2. If the student goes up the class, they cannot use Wetracy anymore.

The research results show a relationship between Wetracy media and the character of student self-reliance that lies in the content of Wetracy content that is packaged in science literacy activities. First, there is a connection about the feeling of self-reliance. Wetracy made several menus to read, video menus to training self-attitude with the content of activities that call for students to conduct simple experiments at home. Wetracy also ensures the development of self-reliance character by bringing up a quiz menu so that teachers and parents can know if Wetracy effectively develops the character of student self-reliance.

However, other studies say that the use of media has not been fully effective in improving the character of student independence in learning. This statement is demonstrated by research that states that multimedia e-learning in independent science learning in elementary schools is still less effective in increasing student independence (So et al., 2019). However, compared to 
audio, video, and other media, autonomous learning materials improve students' skills, academic ability, and independence during the pandemic (Xie, 2020). In addition, the independence of students can be honed by the implementation of an inquiry-based learning model on science learning, especially for students in grades 1 to 4 of elementary school (Letina, 2020).

Therefore, increasing the independence of learners can be done through various aspects. Of course, the character can not only be realized by a medium. The most important supporting component to develop self-reliance is through concrete examples of parents, teachers, and the surrounding environment that always provide examples and positive support to students. Media literacy and science literacy can be two aspects that can develop learners to be innovative and can create new or creative perspectives in presenting ideas from the results of watching science videos or accessing scientific information on the internet and social media (Rosenthal, 2020).

Wetracy, as one of the media, presents to improve the character of selfreliance, also needs support from related parties. Maximizing the purpose of Wetracy is a challenge for teachers and parents to work together in developing student independence, but in this online learning, parents or teachers need to select and continue to supervise the use of media and the internet by students.

\section{CLOSING}

Using the website is said to be effective and instill character value and increase learners' independence. Wetracy media can train, develop, and stimulate student independence such as courageous attitude, creativity, challenging, professional, hard work, and the fighting power to be a lifelong learner. That is proven by validating media, material, and language experts who say that Wetracy with the content of science literacy activities can be categorized as "very feasible" to develop the character of self-reliance of grade 2 learners. Wetracy is just part of the media development efforts to build the character of student selfreliance. Without the integration of parents and students, the planting of this character will not run to the maximum. Indicators in the character of student independence should be seen in each content on the website, so 
media developers and teachers need to pay attention to this aspect in designing science literacy activities. Other forms of questions and activities as science literacy on the features presented in the website should be observed and considered again.

The next researcher's research is about the relationship of digital literacy related to student independence. The success of the supervision of the implementation of online science literacy activities using the website media will be helpful as a discovery in terms of character planting. Indeed, this study has limitations. This study only took samples from 25 students at Pondok Kelapa Elementary School 04, Jakarta, Indonesia. The following research is expected to examine all elementary school students located in Jakarta, Indonesia.

\section{ACKNOWLEDGMENTS}

We want to thank the teachers and students of grade 2 at Pondok Kelapa elementary school 04, Jakarta, Indonesia, for being willing to be resource persons and respondents for data needs in this article's research. We are also grateful to the Primary School
Teacher Education Study Program, Universitas Negeri Jakarta, which has opened a Scientific Publication course to realize this research.

\section{REFERENCES}

Agung, Iskandar, Widiputera, Ferdi, \& Widodo. (2019). The Effect of The use of Gadget on Psychosocial, Socio- Emotional, Self-Reliance, Responsibility, and Students Learning Results in Elementary School. Education Quarterly Reviews, 2(2). https://doi.org/10.31014/aior.1993. 02.02.60

Asrial, Syahrial, Maison, Muhaimin, \& Kurniawan, D. A. (2020). Eassessment for characters independence. International Journal of Interactive Mobile Technologies, 14(15), 125-141. https://doi.org/10.3991/IJIM.V14I 15.12995

Beheshti, M., Taspolat, A., Kaya, O. S., \& Sapanca, H. F. (2018).

Characteristics of instructional videos. World Journal on Educational Technology: Current Issues, 10(2), 79-87. https://doi.org/10.18844/wjet.v10i 2.3418 
Çoruk, A. (2018). School Principals'

Opinions about Public Relations

Practices on Schools. International

Journal of Progressive Education, 14(2), 136-147.

https://doi.org/10.29329/ijpe.2018.

139.10

Dwyer, K. O. (2012). Emerson's

Argument for Self-reliance as a

Significant Factor in a Flourishing

Life. Journal of Philosophy of Life, 2(1), 102-110.

Eccles, J. S. (1999). Eccles1999. JSTOR, 9(2), 30-44.

Education, C. (2018). Toys and Play : 6to 8-Year Olds. Seattle Children's Hospital Research Foundation, 12.

https://www.seattlechildrens.org/h

ealth-safety/keeping-kids-

healthy/development/toys-and-

play-6-to-8-year-olds/

Ferraro, S., Adamo, A., Armeri, G. M., Bennici, C., Biondo, G., Bondì, S., Di Natale, M., Giannettino, A., Patti, C., \& Masullo, T. (2019). How a good video can remove 'barriers' for a more inclusive science communication. $C N R$ SOLAR, 1-5.

Gilchrist, K., \& Polizz, G. (2019).
Changing media habits mean

having a conversation with children is more important than ever. THE LONDON SCHOOL OF ECONOMICS AND POLITICAL SCIENCE. https://blogs.lse.ac.uk/parenting4di gitalfuture/2019/02/05/changingmedia-habits-mean-having-aconversation-with-children-ismore-important-than-ever/ Hendarman, et al. (2017). Konsep dan Pedoman Penguatan Pendidikan Karakter. In L. Muliastuti (Ed.), Kemendikbud (2nd ed.).

Sekretariat TIM PPK

Kemendikbud.

file://C:/Users/User/Downloads/fv m939e.pdf

Intania, E. V., \& Sutama. (2020). The role of character education in learning during the COVID-19 pandemic Peran pendidikan karakter dalam pembelajaran selama pandemi. Jurnal Penelitian Ilmu Pendidikan, 13(2), 129-136.

Kemendikbud. (2016). Kebijakan Penguatan Pendidikan Karakter. Pusat Penguatan Karakter. https://cerdasberkarakter.kemdikbu d.go.id/?page_id=132 
Kopzhassarova, U., Akbayeva, G.,

Eskazinova, Z., Belgibayeva, G.,

\& Tazhikeyeva, A. (2016).

Enhancement of students'

independent learning through their

critical thinking skills

development. International

Journal of Environmental and

Science Education, 11(18), 1158511592.

Letina, A. (2020). Development of

Students' Learning to Learn

Competence in Primary Science.

Education Sciences, 10(11), 1-14.

https://doi.org/10.3390/educsci101

10325

Lumbantobing, W. L., \& Haryanto. (2019). Effect of ARCS Model on Learning Independence of 21st Elementary School. Journal of Physics: Conference Series, 1233(1).

https://doi.org/10.1088/17426596/1233/1/012105

Maharani, D. W., \& Dewi, N. R. (2015).

The implementation of science inquiry-based website oriented by cultural deviance solution to instill students' character and independence. Jurnal Pendidikan IPA Indonesia, 4(1), 25-30. https://doi.org/10.15294/jpii.v4i1.3 497

Mateer, D., Purdom, R., Ghent, L. S., \& Porter, T. (2012). Why Use Media to Enhance Teaching and Learning. Pedagogy in Action Connecting Theory to Classroom Practice.

https://serc.carleton.edu/sp/library/ media/why.html

Morgan, H. (2020). Best Practices for Implementing Remote Learning during a Pandemic. The Clearing House: A Journal of Educational Strategies, Issues and Ideas, 93(3), 135-141.

https://doi.org/10.1080/00098655. 2020.1751480

Mujahidin, E., Ruhenda, R., \& Nasution, S. A. (2018). Effective SelfReliance Teaching Model Using Visual Storytelling for Elementary Students in Indonesia. Unnes Science Education Journal, 7(2), 129-139.

https://doi.org/10.15294/usej.v7i2. 22091

Muttaqin, M. F., Raharjo, T. J., \& Masturi. (2018). The Implementation Main Values of Character Education 
Reinforcement in Elementary

School. Journal of Primary

Education, 7(1), 103-112.

https://doi.org/10.15294/jpe.v7i1.2 2766

Nurazizah, R. (2021). An independent character of students in learning during the pandemic.

ETUDE:Journal of Educational

Research, 1(2), 51-60.

OECD. (2003). Literacy Skills for the World of Tomorrow Further results from PISA 2000.

Ozturk, G., \& Ohi, S. (2018).

Understanding young children's attitudes towards reading in relation to their digital literacy activities at home. Journal of Early Childhood Research, 16(4), 393-406.

https://doi.org/10.1177/1476718X 18792684

Prasetiyo, E., \& Baswedan, A. R. (2020). Implementation of Character Education By Establishing A Special Task Force In Muhammadiyah Karangkajen Elementary School. 9(03), 121127.

Puspitaningrum, E., \& Ismaniati, C. (2020). The Implementation of
Independent Character Education in SD N Terbansari 1, Yogyakarta. 398(ICoSSCE 2019), 35-39. https://doi.org/10.2991/assehr.k.20 0130.008

Puspitarini, Y. D., \& Hanif, M. (2019). Using Learning Media to Increase Learning Motivation in Elementary School. Anatolian Journal of Education, 4(2), 53-60. https://doi.org/10.29333/aje.2019.4 26a

Rasmitadila, Aliyyah, R. R., Rachmadtullah, R., Samsudin, A., Syaodih, E., Nurtanto, M., \& Tambunan, A. R. S. (2020). The perceptions of primary school teachers of online learning during the covid-19 pandemic period: A case study in Indonesia. Journal of Ethnic and Cultural Studies, 7(2), 90-109.

https://doi.org/10.29333/ejecs/388 Rosenthal, S. (2020). Media Literacy, Scientific Literacy, and Science Videos on the Internet. Frontiers in Communication, 5(September), 1-7.

https://doi.org/10.3389/fcomm.202 0.581585

Rosilia, P., Yuniawatika, \& Murdiah, S. 
(2020). Strengthening of

Independent Character Through

Online Learning in Elementary

School. 1st International

Conference On Information

Technology And Education (ICITE

2020), 508(Icite), 251-256.

https://doi.org/10.2991/assehr.k.20

1214.245

Royana, N. I., Asrowi, \& Mulyoto.

(2019). The Role of Group

Counseling Service Using

Brainstorming Technique in

Improving Students' Learning

Independence. 326(Iccie 2018),

361-365.

https://doi.org/10.2991/iccie-

18.2019 .61

Scholastic Parents Staff. (2020). The

Guide to 2nd Grade: Reading and

Writing. Scholastic.

https://www.scholastic.com/parent

s/school-success/school-success-

guides/guide-to-2nd-grade.html

School, P. Y. (2020). Character

Education in schools -

Coronavirus lockdown. Promote

Your School.

https://www.promoteyourschool.c

o.uk/blog/character-education-in-

schools-coronavirus
Setyowidodo, I., Pramesti, Y. S., \&

Handayani, A. D. (2018). Problem

based learning: The effect of real

time data on the website to student

independence. Journal of Physics:

Conference Series, 1013(1).

https://doi.org/10.1088/1742-

6596/1013/1/012073

Shaffer, D. R., \& Kipp, K. (2010).

Developmental Psychology:

Childhood and Adolescence,

Eighth Edition (8th ed.).

WADSWORTH CENGAGE

Learning.

https://doi.org/10.1146/annurev.ps.

41.020190 .002131

So, W. W. M., Chen, Y., \& Wan, Z. H. (2019). Multimedia e-Learning and Self-Regulated Science Learning:

a Study of Primary School

Learners' Experiences and

Perceptions. Journal of Science

Education and Technology, 28(5),

508-522.

https://doi.org/10.1007/s10956-

019-09782-y

Sukowati, S., Sartono, E. K. E., \& Pradewi, G. I. (2020). The effect of self-regulated learning strategies on the primary school students' independent learning skill. 
Psychology, Evaluation, and

Technology in Educational

Research, 2(2), 81.

https://doi.org/10.33292/petier.v2i

2.44

Suprani, \& Hendracipta, N. (2019).

DEVELOPMENT OF

CHARACTER EDUCATION IN

ELEMENTARY SCHOOL

THROUGH MACROMEDIA

FLASH FOKLORE. JPSD, 5(2), 180-192.

Suwardani, N. P. (2020). "Quo Vadis"

Pendidikan Karakter Dalam

Merajut Harapan Bangsa Yang

Bermanfaat. In I. W. Wahyudi

(Ed.), UNHI Press (1st ed.). UNHI PRESS.

UNICEF. (2021). Final Report

SITUATIONAL ANALYSIS ON

DIGITAL LEARNING.
Xie, Z. (2020). Effectiveness of

Autonomous Learning Materials

for Students during the COVID-19

Pandemic: A Case Study of the

Daxie Second Elementary School

in Ningbo, Zhejiang, China.

Science Insights Education

Frontiers, 6(1), 613-624.

https://doi.org/10.15354/sief.20.or

023

Zhou, L., Wu, S., Zhou, M., \& Li, F. (2020). 'School's Out, But Class'

On', The Largest Online Education in the World Today: Taking

China's Practical Exploration

During The COVID-19 Epidemic

Prevention and Control As an

Example. SSRN Electronic

Journal, 4(2), 501-519.

https://doi.org/10.15354/bece.20.ar

023 